\title{
Die invloed van Suid-Afrika se isolasie op landbounavorsing
}

Die primere doel van landbounavorsing is om kennis en kundigheid te genereer wat in prakliese. bio-ekonomies doeltreffende produksiestelsels opgeneem kan word. Vir die praktyk moet navorsing gerig wees op die bevordering van volgehoue ekonomiese produksie van landbouprodukte van alanvaarbare gehalte teen 'n bekostigbare prys aan 'n grociende bevolking. sonder dat die instandhouding van natuurlike hulpbronne bedreig word. Stygende produksietendense van die meeste landbouprodukte is sedert dic middel-sestigerjare watargeneem (Kortbegrip van Landboustatisticke, 1993) ten spyte van drie ernstige droogtes tydens hierdie periode. Indien dic aansienlike onttrekking van landbougrond uit produksie (deur onteiening vir konsolidasiedoeleindes, wild- of ontspanningsplase, dorpsontwikkeling, ens.) in ag geneem word, kan dit die indruk laat dat die gevolge van isolasie nie so ernstig was nie. Met ander woorde, dat die vakkundige bediening deur navorsing en tegnologie-oordraging toereikend in stand gehou is.

So 'n afleiding sou egter oppervlakkig en slegs gedeeltelik korrek wees, omdat dit ander aspekte ignoreer.

Navorsers wat blootstelling aan die isolasicjare gehad het, se standpunte en ervarings is uiteenlopend. Sommige navorsers en hulle navorsing is skynbaar veel minder geraak as ander. Trouens, die getuienis van sommige dui daarop dat navorsing in sekere gevalle selfs deur isolasic mag gebaat het.

Dit is welbekend dat talle navorsers deur eic inisiatief suksesvol daarin geslaag het om goeie kontak en kommunikasie met oorsese kollegas tydens hierdie periode op te bou en te handhataf. Datar is talle voorbeelde van onkonvensionele metodes wat gevolg is om selfs eksperimentele materialal in dic hande te kry. Net soos die geval was by baie ander instansies, was daar wisselende grade van isolasie - vanaf totale tot bykans geen versteuring in normale kommunikasic op persoonlike en institusionele vlak nie. Die aard van die isolering het ook gewissel valn die meer subticle tot die blatante en vernederende.

Om bydertydse kennis, insig, visic, vakkundige ingeskerptheid en konseptuele denke te stimuleer en te verseker, kan 'n navorser nie slegs aangewys wees of staatmatak op onpersoonlike kontak, tydskrifte, joernale, ens. nie. Dit is veral in dié opsig walar navorsing merkbaar getref is en watar daar as gevolg van isolasie 'n agterstand op verskeic navorsingsterreine opgebou is. Daar is geen plaasvervanger vir eerstehandse gesprekvocring, gedagteuitruiling en voortgesette opleiding nie. Agterstande het ontstaan omdat navorsers se volwalrdige deelname aan die intellektuele aktiwiteite van die internasionale wetenskaplike gemeenskap aan bande gelê is. Afgesien van die lande wat visums alan Suid-Afrikaners geweier het, was daar talle lande (Skandinawië, Finland. Ierland, ens.) wat die bywoning van kongresse, simposia, ens. verbied het. In ander gevalle het sekere akademiese inrigtings geweier om Suid-Afrikaanse navorsers of nagraadse studente te ont vang (VSA, Kanada, Skandinawië, Indië, ens.) Walar Suid-Afrikatanse navorsers nog tocgelaat is om konferensies, ens. by te woon, is hulle gerelegeer na 'n niedeelnemende status. Hulle is selde opgeneem in die formele program van uitnodigings- en ander referate of as sessicvoorsitters - om nic cers te praat van lidmaatskap van kundigheids- en bestuurskomitees nie.

Die geleentheid is Suid-Afrikaanse landbounavorsers op die wyse ontneem om volwaardig betrokke te raak in die beoefening van hulle vakkundigheid en om die gehalte en relevansie van plaaslike navorsing bekend te stel en gedaag te kry, sowel as om dit intellektueel te verantwoord tecnoor ' $n$ wyer en meer kritiese gemeenskap. Hierdie gebrekkige blootstelling laat baie Suid-Afrikaanse navorsers ietwat lomp en met 'n sigbare ongemak, asook 'n tekort aan selfvertroue in die internasionale vergadersale beweeg.

'n Verdere ernstige nagevolg wat van die isolasiejare oorgehou is, is die ontocreikende kennis van die Afrikaanse vasteland, sy potensiaal en groot landbouprebleme. Dalar is ook min kennis oor navorsing wat elders in Afrika gedoen en onderneem word. Terwyl Suid-Afrika in isolasie hom noodgedwonge (en suksesvol) moes toespits op dic noodsaaklike ontwikkeling van sy Eerstewêreldhoëtegnologie-landboubedryf, het die uitdagings van sy eie Derdewêreldlandboubehoeftes agterweë gebly.

Met die opheffing van sy isolasie het Suid-Afrika se landbounavorsing grootliks reeds sy agterstande ingehaal, danksy ook sy deelname alan moderne elektroniese rekenaarkommunikasietegnologic.

Histories en strategies gesien, nieteenstaande dic invloed van isolasic, was Suid-Afrikaners egter nog nooit so goed geplaas om op grond valn bestaande kundigheid en die suksesvolle bydraes wat sy landbounavorsing reeds gelewer het, die talak in Afrika alan te durf nie.

J.H. HOFMEYR 